\title{
Protein synthesis in splanchnic tissues of sheep offered two levels of intake
}

\author{
BY G. E. LOBLEY, ALEXMARY CONNELL, E. MILNE, APRIL M. NEWMAN \\ AND T. A. EWING \\ Rowett Research Institute, Bucksburn, Aberdeen AB2 9SB
}

(Received 2 November 1992 - Revised 8 February 1993 - Accepted 4 March 1993)

\begin{abstract}
Protein synthesis rates were measured in liver and gastrointestinal tract (GIT) sections of fattening sheep offered lucerne (Medicago sativa) pellets at either 1.25 or 2 times energy maintenance. The measurement technique involved a large dose of $\left[1-{ }^{13} \mathrm{C}\right]$ valine over $60 \mathrm{~min}$. Animals on the higher intake had a larger mass of liver protein $(143 v .100 \mathrm{~g}, P=0.02)$, similar fractional synthesis rates $\left(k_{s} ; 22.5 v .22 .1 \% / \mathrm{d}\right.$, not significant) and greater absolute amounts of protein synthesis $(32 \mathrm{v} .23 \mathrm{~g} / \mathrm{d} ; P=0.016)$ compared with those on the smaller amount of ration. The $k_{s}$ values and RNA : protein in the GIT sections also tended to increase with food intake. Estimated total GIT protein synthesis was approximately three-fold that in liver and probably constituted $25-35 \%$ of whole body synthesis. All splanchnic tissues measured had lower translational efficiencies ( $g$ protein synthesized/d per $g$ total RNA) than reported for milk-fed and newly-weaned lambs and this may relate to the decline in the rate of protein deposition as lambs progress to the fattening condition.
\end{abstract}

Protein synthesis: Liver: Gastrointestinal tract: Translational efficiency: Sheep

The intense metabolic activity of the gastrointestinal tract (GIT) and liver are well recognized. In ruminants, for example, the splanchnic tissues comprise less than $10 \%$ of body mass but account for approximately $50 \%$ of total energy expenditure (e.g. Reynolds et al. 1991). Whether a similar contribution is made to protein turnover, a major contributor to cell metabolism, is less certain. This is due to the lack of reliable values for protein synthesis in ruminant splanchnic tissues, with the few data that are available usually obtained by continuous infusion of tracers (e.g. Lobley et al. 1980; Davis et al. 1981; Abdul-Razzaq \& Bickerstaffe, 1989; Eisemann et al. 1989). In this technique, differences in isotopic activity occur between the various free amino acid pools (vascular, extracellular, intracellular etc), due to dilution from protein degradation, with the problem most acute for tissues of rapid turnover, such as liver and the GIT. Uncertainty as to which pool most closely approximates the true precursor for protein synthesis, the aminoacyl-tRNAs, results in variation of three- to four-fold for calculated rates (e.g. Lobley et al. 1980; Davis et al. 1981; Abdul-Razzaq \& Bickerstaffe, 1989; Eisemann et al. 1989).

The large-dose technique, in which the animal receives sufficient amino acid to 'flood' tissue free-amino acid pools and, hence, equalize isotopic activities, has removed this major concern and become the preferred method for rodent studies (Garlick et al. 1980). Extension of the method to ruminants has usually been limited to studies on peripheral tissues (Pell \& Bates, 1987; Lobley et al. 1990, 1992), although splanchnic tissue metabolism was investigated in preruminant and just-weaned lambs (Attaix et al. 1986, 1988; Attaix, 1988) and young rams (Southorn et al. 1992). The current study adapts the method to liver and GIT tissues in fattening lambs and with two aims. First, to examine if protein synthesis in these tissues is as sensitive to chronic intake changes as it is in muscle 
and skin (Lobley et al. 1992). This would then allow the responses in whole-body protein metabolism to nutritional changes (Pell et al. 1986; Oddy et al. 1987; Harris et al. 1992) to be partitioned further between the various tissues. The second aim relates to the observation that muscle translational efficiency $\left(k_{r n a} ; \mathrm{g}\right.$ protein synthesized $/ \mathrm{d}$ per $\mathrm{g}$ total RNA) in ruminants is lower (Bryant \& Smith, 1982; Pell \& Bates, 1987; Eisemann et al. 1989; Lobley et al. 1990; for review see Lobley, 1993) than in young rodents (e.g. Lewis et al. 1984) or preruminants (Attaix, 1988). This may relate to the reduced rates of protein gain (Searle \& Graham, 1987) and/or insensitivity of peripheral tissue protein synthesis to exogenous insulin (Oddy et al. 1987; Early et al. 1988) in the fattening ruminant. It was, therefore, of interest to determine whether low $k_{r n a}$ values were also a feature of the visceral components and might, therefore, represent a generalized ontological response rather than a specific effect on the major protein storage tissue, skeletal muscle. Part of these findings have been reported in review form (Lobley, 1993).

\section{METHODS}

\section{Animals and diets}

Six Suffolk cross-bred wether lambs selected at approximately 8 months of age and weighing $35-38 \mathrm{~kg}$ were accustomed to receiving a diet of lucerne (Medicago sativa) pellets (10.5 MJ metabolizable energy and $25 \mathrm{~g} \mathrm{~N} / \mathrm{kg}$ dry matter (DM)) from frequent (hourly) feeders, while housed in individual metabolism crates. Three sheep were offered $720 \mathrm{~g}$ $\mathrm{DM} / \mathrm{d}$ and the remainder $1440 \mathrm{~g} \mathrm{DM} / \mathrm{d}$; these approximated to intakes of 1.2 and 2 times energy maintenance respectively, based on an energy maintenance requirement for confined older lambs of $400 \mathrm{~kJ} / \mathrm{kg}$ body-weight ${ }^{0.75}$, at the final experimental weights. To ensure adequate acclimatization and stabilization of visceral organ size, each animal was maintained under the experimental conditions for a minimum of 4 weeks (Burrin et al. 1990).

\section{Isotope procedures}

At least $3 \mathrm{~d}$ before the large-dose procedure the animals were prepared with a temporary polyvinyl chloride catheter in each external jugular vein under local anaesthesia (Lobley et al. 1990). On the day of the experiment a sample of blood was taken before the large-dose injection for determination of natural enrichment of plasma free and protein-bound valine. Then the large dose, consisting of a sterile solution of $14 \mathrm{~g}$ valine (hospital grade; Forum Chemicals, Surrey) plus $1 \mathrm{~g}\left[1-{ }^{13} \mathrm{C}\right]$ valine ( 99 atoms \% ; Tracer Technologies, Massachusetts, USA) in $200 \mathrm{ml}$ water, was slowly injected over a $15 \mathrm{~min}$ period. Blood samples (for plasma preparation) were removed at $5 \mathrm{~min}$ intervals during the first $30 \mathrm{~min}$ after the start of the injection and every $10 \mathrm{~min}$ thereafter. At $60 \mathrm{~min}$ the animal was killed by an intravenous overdose of pentobarbitone and portions of tissue excised rapidly from the liver, rumen (ventral sac), abomasum, duodenum (first $400 \mathrm{~mm}$ after pylorus), jejunum (to encompass pancreatic area), ileum (last $250 \mathrm{~mm}$ ), caecum and colon. All samples were washed in cold $\left(4^{\circ}\right)$ saline $(9 \mathrm{~g} \mathrm{NaCl} / 1)$ and the small intestine sections were then separated into mucosal and serosal components by gentle scraping with a microscope slide. All tissue and plasma samples were then frozen in liquid $\mathrm{N}_{2}$ and stored at $-20^{\circ}$ for further processing. Time from death to freezing of all tissues was less than $10 \mathrm{~min}$.

\section{Chemical and stable isotope analyses}

Plasma samples were deproteinized with sulphosalicyclic acid (final concentration $70 \mathrm{~g} / \mathrm{l}$ ) and the supernatant fraction treated as described by Lobley et al. $(1990,1992)$. Preparation of tissue for quantification of total RNA and protein concentrations and isolation of free- 
and protein bound-valine by ion-exchange chromatography was as reported earlier (Lobley et al. 1990). Enrichments of plasma and tissue free valine were determined as the tertiary butyl-dimethylsilyl derivative by electron-impact selective-ion monitoring on a VG Trio-1 gas-liquid chromatograph mass spectrometer (VG MassLab, Manchester). Enrichment of $\left[1-{ }^{13} \mathrm{C}\right]$ valine isolated from tissue and plasma proteins was measured following release of the carboxyl carbon as $\mathrm{CO}_{2}$ by the ninhydrin procedure, as described by Read et al. (1984) and as modified by Lobley et al. (1990). Measurements were made relative to Peedee Belemnite on a SIRA 12 isotope-ratio mass spectrometer (VG Isogas, Middlewich, Cheshire). Protein and RNA measurements were by the chemical procedures described previously (Lobley et al. 1990).

\section{Calculations}

The fractional rate of tissue protein synthesis $\left(\times 100 ; \mathrm{FSR}, k_{s}\right)$ was calculated from the formula of Garlick et al. (1980).

$$
k_{s}=\left(P_{\mathrm{t}}-P_{0}\right) / A
$$

where $P_{0}$ and $P_{\mathrm{t}}$ are enrichments (atoms $\%$ ) of protein-bound valine at times 0 and $t$ respectively and $A$ is the area under the free amino acid curve selected for precursor enrichment (i.e. atoms \% excess (ape) $\times$ time (d)), calculated by trapezium-based analysis. Plasma protein taken before injection of the enriched valine solution was assumed representative of the natural enrichment for all tissue proteins (i.e. the $P_{0}$ value). This has been shown to be a valid approach for other amino acids and tissues in sheep (e.g. Lobley et al. 1990). Since the sheep received a long period of adjustment to the diet and the synthesis rates of the visceral tissues were expected to be much greater than those in the peripheral tissues examined in the earlier studies (Lobley et al. 1990, 1992), any small differences between plasma and tissue protein-bound valine natural enrichments were considered to produce non-significant effects. The area $\mathrm{A}$ was calculated from the plasma curve, adjusted for the relative enrichment of the free valine in tissue compared with plasma in the terminal samples.

Translational efficiency $\left(k_{r n a}\right)$ was calculated from:

$$
k_{s} / C_{s},
$$

where $C_{s}$ is total RNA: protein in the tissue.

\section{Statistics}

Results were analysed either by the Student $t$ test, with variances assumed not equal, for effects of intake or as paired samples for mucosal and serosal comparison.

RESULTS

All sheep gained weight; on the day of experiment the mean weights were 40 (SEM 1.5 ) $\mathrm{kg}$ and 48 (SEM 7.5) $\mathrm{kg}$ for the lower (M) and higher $(\mathrm{H})$ intakes respectively with corresponding live-weight gains over the previous 3 weeks of 5 (SEM 10) g/d and 210 (SEM 25) g/d.

The temporal change in plasma free valine enrichment showed a similar pattern to that reported for leucine (Lobley et al. 1990). With the quantity injected, approximately ten times the body free valine pool, the enrichment at $60 \mathrm{~min}$ was $95 \%$ that of the maximal 


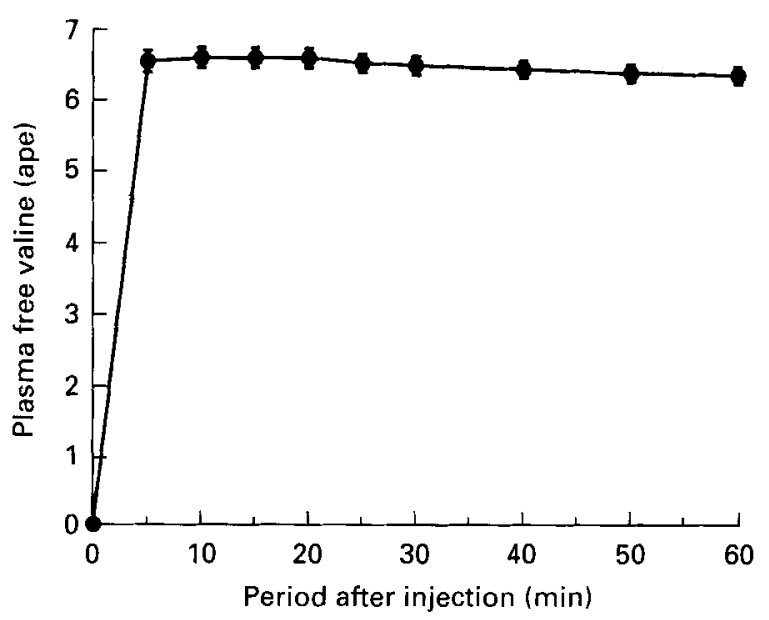

Fig. 1. The time-course of the enrichment (atoms percent excess; ape) of plasma free valine after intravenous injection of a mixture of $14 \mathrm{~g} \mathrm{~L}$-valine pus $1 \mathrm{~g} \mathrm{~L}-\left[1-{ }^{13} \mathrm{C}\right]$ valine. Values are means with their standard errors, represented by vertical bars, for six sheep. For details of procedures, see pp. 4-5.

value (6-6.5 ape) obtained within 5 min of start of injection (Fig. 1). Compared with either leucine or phenylalanine, the two other amino acids most commonly used for large-dose studies, valine has a lower protein-bound:free amino acid value (Attaix et al. 1986) and, thus, the rate of disposal of the excess dose through the synthetic route would be less.

At slaughter the mean enrichment of free valine in the tissues, compared with that in the terminal plasma sample, was 0.97 (SD $0.01 ; n 66$ ). The lowest enrichments were found for mucosal samples, with the largest difference 0.91 of the plasma value.

There were no significant differences in protein concentrations for any tissues at either intake (Table 1). RNA concentrations tended to be greater for sheep at the higher intake, but these were only significant $(P<0.05)$ for rumen and abomasum (Table 1). The RNA: protein value, $C_{s}$, also tended to be greater at the higher intake, but this difference reached statistical significance $(P<0.05)$ only for the rumen, abomasum and duodenal mucosa (Table 1), although there was a similar trend for the caecum $(P<0 \cdot 1)$.

Liver size was greater in absolute weight $(918 v .623 \mathrm{~g} ; P=0.002)$, protein content (143 v. $105 \mathrm{~g} ; P=0.02)$ and relative to live weight $(19.2 v .15 .5 \mathrm{~g} / \mathrm{kg} ; P=0.075)$ for the higher intake animals. However, FSR for liver was similar for all sheep, i.e. unaffected by intake (Table 2).

Other tissues were less consistent between sheep, with a trend towards greater rates at the higher intake (Table 2), although statistical significance was not attained, possibly due to the small numbers of animals involved and the heterogeneity of this group of sheep. Mucosal $k_{s}$ always exceeded the serosal value for individual sections; these differences bordered on statistical significance within each intake (Table 2), but combined across both intakes the differences were highly significant (duodenum $P<0.002$, jejunum $P=0.009$, ileum $P<0.002$ ). The FSR values obtained for the various GIT sections are similar to those recently reported by Southorn et al. (1992) when comparable modes of calculation are applied.

The trend of higher $k_{s}$ and $C_{s}$ with increased intake meant that translational efficiency was similar between ration levels (Table 2). While there was some variation in $k_{r n a}$ between the tissues the majority of calculated values were less than $10 \mathrm{~g}$ protein synthesized/d per $\mathrm{g}$ total RNA, with the rates in the mucosal tissues slightly greater. Again the trend was, for 
PROTEIN SYNTHESIS IN OVINE SPLANCHNIC TISSUES

:

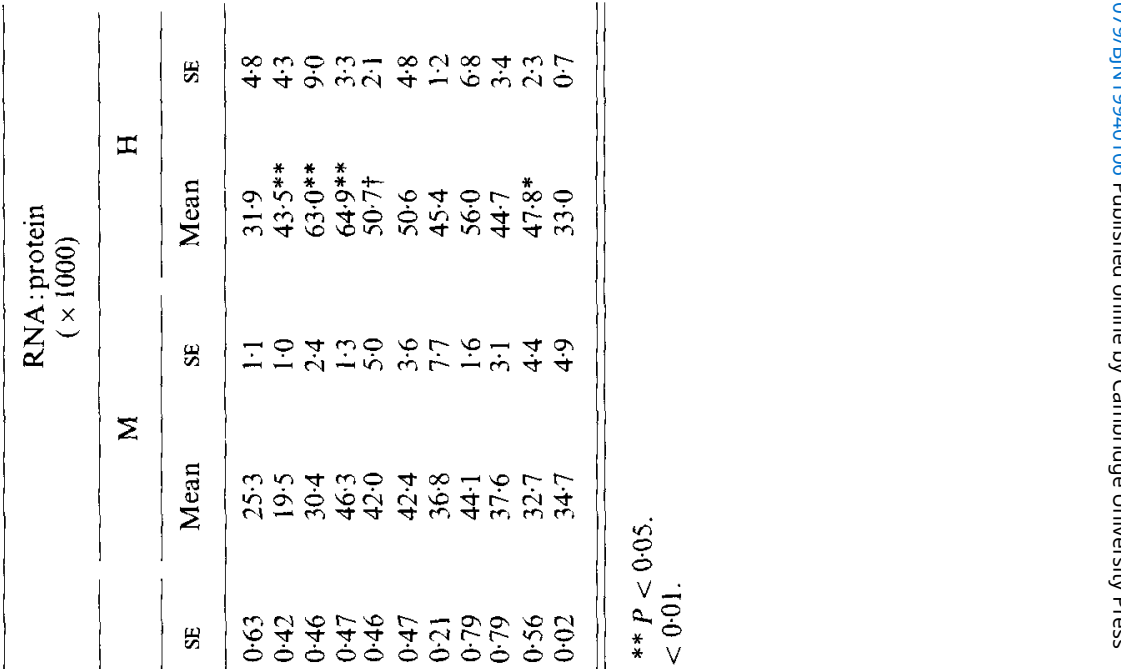

$\stackrel{2}{2}$

吾旅

s.

I

$\Xi \check{c}$

I

- 00000000000

is

בิ

$\div \div \overline{0}$

$\ddot{\nabla} \Omega$ क्ष

$\sum_{\Sigma}$

$\Xi N$

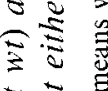

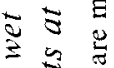

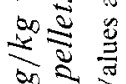

$\overbrace{2}^{2}$

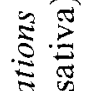

|

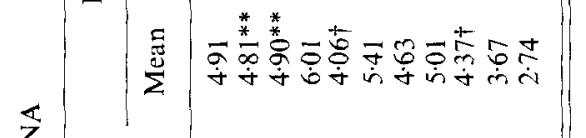

bे

*

$\simeq$

|س

s。

要总的

$\Sigma$

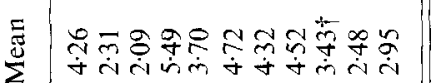

형형

$\vec{\exists}$

象象密

2

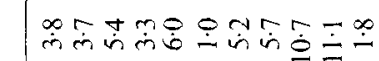

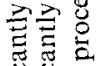

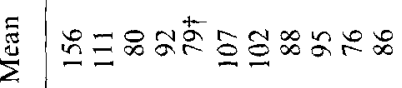

绕焉

क.

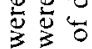

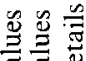

要雱

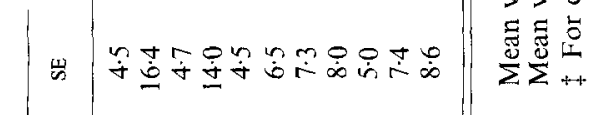

$\Sigma$

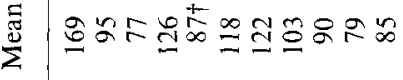

$\sum_{2}^{\top}$

$\overparen{3}$

క

2

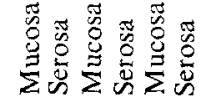

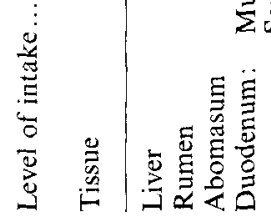

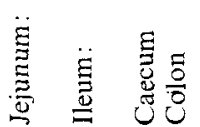


Table 2. Fractional synthesis rates $\left(\mathrm{k}_{\mathrm{s}} \times 100\right)$ and translational efficiency $\left(\mathrm{k}_{r n a} ; \mathrm{g}\right.$ protein synthesized/d per $g$ RNA) in splanchnic tissues from sheep fed on lucerne (Medicago sativa) pellets at either $720(M)$ or $1440(H) g$ dry matter $/ d \$$

(Mean values with their standard errors for three animals)

\begin{tabular}{|c|c|c|c|c|c|c|c|c|c|}
\hline \multirow{3}{*}{\multicolumn{2}{|c|}{ Level of intake... }} & \multicolumn{4}{|c|}{$\begin{array}{c}k_{s}^{\dagger} \\
(\% / \mathrm{d})\end{array}$} & \multicolumn{4}{|c|}{$\left(\begin{array}{c}k_{r n a} \\
\left(10 \times k_{s} \times \text { protein } / \text { RNA }\right)\end{array}\right.$} \\
\hline & & \multicolumn{2}{|c|}{ M } & \multicolumn{2}{|c|}{$\mathrm{H}$} & \multicolumn{2}{|c|}{ M } & \multicolumn{2}{|c|}{$\mathrm{H}$} \\
\hline & & Mean & $\mathrm{SE}$ & Mean & SE & Mean & $\mathrm{SE}$ & Mean & SE \\
\hline Liver & & $22 \cdot 1$ & $0 \cdot 7$ & $22 \cdot 5$ & $1 \cdot 2$ & $8 \cdot 5$ & 0.5 & $7 \cdot 5$ & $1 \cdot 0$ \\
\hline Rumen & & 21.9 & $2 \cdot 1$ & $35 \cdot 3$ & $4 \cdot 7$ & $10 \cdot 9$ & 0.5 & $8 \cdot 1^{*}$ & 0.8 \\
\hline Abomasum & & $23 \cdot 5$ & 1.7 & $28 \cdot 4$ & $5 \cdot 5$ & $7 \cdot 8$ & 0.8 & $5 \cdot 2$ & 1.6 \\
\hline \multirow[t]{2}{*}{ Duodenum: } & Mucosa & $59 \cdot 5$ & $3 \cdot 3$ & $67 \cdot 5$ & $6 \cdot 3$ & $12 \cdot 2$ & 0.8 & $10 \cdot 3$ & 0.5 \\
\hline & Serosa & $41 \cdot 6 \dagger$ & $4 \cdot 3$ & $44.9+\dagger$ & $3 \cdot 2$ & $9.5+\dagger$ & 0.6 & 9.9 & $0 \cdot 4$ \\
\hline \multirow[t]{2}{*}{ Jejunum: } & Mucosa & $64 \cdot 4$ & $9 \cdot 1$ & $66 \cdot 9$ & $2 \cdot 2$ & 13.5 & 0.9 & $12 \cdot 6$ & 0.9 \\
\hline & Serosa & $35 \cdot 7+\dagger$ & $5 \cdot 7$ & $49 \cdot 3 \dagger$ & $6 \cdot 3$ & $9 \cdot 7 \dagger$ & 0.6 & $10 \cdot 8$ & 1.4 \\
\hline \multirow[t]{2}{*}{ Ileum: } & Mucosa & $47 \cdot 3$ & $4 \cdot 4$ & $56 \cdot 7$ & 6.6 & $10 \cdot 2$ & 0.5 & $10 \cdot 2$ & 02 \\
\hline & Serosa & $30 \cdot 5$ & $2 \cdot 0$ & $40 \cdot 7^{* \dagger}$ & 28 & $8 \cdot 1$ & $1 \cdot 2$ & $9 \cdot 1$ & 0.3 \\
\hline Caecum & & $20 \cdot 4$ & $1 \cdot 2$ & $34 \cdot 1$ & $7 \cdot 0$ & $6 \cdot 3$ & 0.6 & $9 \cdot 4^{*}$ & 0.8 \\
\hline Colon & & 260 & $2 \cdot 3$ & $35 \cdot 0$ & $4 \cdot 0$ & $7 \cdot 4$ & 0.5 & $10 \cdot 6$ & $1 \cdot 2$ \\
\hline
\end{tabular}

Mean values were significantly different from those for $\mathrm{M}: * P<0 \cdot 1$.

Mean values were significantly different from those for mucosa for both intakes: $\uparrow P<0 \cdot 1, \uparrow \uparrow P<0.05$

$\$$ For details of diet and procedures, see pp. 45 .

data combined across both intakes, for mucosal translational efficiency to exceed serosal (duodenum $P=0.061$, jejunum $P=0 \cdot 017$, ileum $P=0.072$ ).

\section{DISCUSSION \\ Large-dose procedure}

The advantages and current controversies of this method have been reviewed extensively elsewhere (Garlick et al. 1980; Attaix et al. 1986; Lobley et al. 1990). The use of valine eliminates certain hormonal perturbations caused by other amino acids (Kuhara et al. 1991) and, where fed animals are studied (see Lobley et al. 1992), the measures of tissue protein FSR obtained are more reliable than with continuous infusion of tracer amounts of amino acids. Particular difficulties with the splanchnic tissues include the presence of rapidly turning-over proteins (e.g. apoprotein B100, sucrase-isomaltase (EC 3.2.1.48)) and the magnitude of secretory activity. Both problems may lead to erroneous values. Protein with small pools, but high turnover, may reach 'plateau' isotopic activity very rapidly and, thereafter, not continue to contribute to the rise in total tissue protein activity that occurs with time. As the measurement time lengthens the extent of underestimating protein synthesis increases and, in this regard, the usually shorter-term large-dose procedure will be superior to continuous-infusion approaches, but not ideal. Similarly, protein synthesized and exported during the experimental period will not be included in the value obtained but, again, the underestimate obtained will be less with the shorter largedose procedure. It is impossible with our current state of knowledge to assess the extent of these problems but Southorn et al. 1992 observed a time related decline in GIT $k_{s}$ under less effective 'flooding' conditions than obtained in the current study. 


\section{Splanchnic protein synthesis}

The few data available for protein synthesis rates in either liver or GIT components of ruminants show considerable variability regardless of whether the intracellular or plasma (given in parentheses) free amino acid isotopic activity is selected as precursor. In the ovine, for example, FSR values for liver range from 22 to 57 (9 to 31)\%/d (Davis et al. 1981; Schaefer et al. 1986; Abdul-Razzaq \& Bickerstaffe, 1989; Lobley et al. 1992). Comparable values in cattle range from 14 to 38 (3 to 11$) \% / d$ (Lobley et al. 1980; Eisemann et al. 1989; Early et al. 1990). Rates in the ovine rumen are also variable 10-70 (plasma 10-17)\%/d (Davis et al. 1981; Schaefer et al. 1986; Abdul-Razzaq \& Bickerstaffe, 1989). Such variation may be associated with choice of a single, representative precursor pool and, in the study of Schaefer et al. (1986), the infusion of various amounts of leucine (a quasi-large-dose procedure) rapidly reduced the three-fold difference between FSR estimations based on plasma $\left(k_{s p}\right)$ and tissue homogenates $\left(k_{s h}\right)$ free amino acid isotopic activity. Their values for liver protein synthesis $(20-22 \% / d)$, at the higher rate of leucine infusion, were between measurements calculated as $k_{s p}(12 \% / \mathrm{d})$ and $k_{s h}(35 \% / \mathrm{d})$ in control animals, which may indicate the isotopic activity of true precursor may be intermediate between that from the two easily-measured free amino acid pools. Rates of $20-26 \% / \mathrm{d}$ for ovine hepatic synthesis were also obtained based on the large-dose technique using either phenylalanine (Lobley et al. 1992; Southorn et al. 1992) or valine (current study), providing a consistent value from separate studies, and with use of different amino acids as isotopic markers.

The ovine liver appears insensitive, at least in terms of FSR, to chronic alteration of intake, although small changes were observed in an earlier study where less effective 'flood' conditions were observed at slaughter (Lobley et al. 1992). This is similar to the situation for intake-restricted rats, where a small or no change in FSR was observed compared with animals fed ad lib. (Merry et al. 1987), although total weight and protein mass of liver were substantially reduced. In consequence, rodent total hepatic protein synthesis $\left(A_{s}\right)$ was significantly different between the intakes. Again, this is reflected in the current study where $A_{s}$ was significantly greater at the higher intake $(32 v .23 \mathrm{~g} / \mathrm{d} ; P=0.016)$, but this response was due to changes in protein mass and not FSR. The response in liver mass (expressed as $\mathrm{g} / \mathrm{kg}$ live body weight) to intake $(+25 \%)$ is less in the present study than that observed $(+61 \%)$ by Burrin et al. (1990) but this may be due, in part, to the smaller differences in intake. The constancy of FSR suggests that liver constitutive protein mass is regulated primarily by alterations in protein degradation.

The situation with the GIT sections is less clear. Total mass was not determined in these studies, but others (e.g. Burrin et al. 1990) have reported both the stomach and small intestine weight increase with intake, although proportionally less than for the liver. Most components of the GIT showed a tendency to higher FSR as intake increased although this was usually not significant. Whether this is a feature of the small number of animals and the associated biological variability or, alternatively, indicates that the GIT is also unresponsive is not clear. In lambs, the transition from the milk-fed to the ruminant state is accompanied by significant increases in FSR (Attaix et al. 1988) and $A_{s}$ (Attaix, 1988) for both the rumen and small intestine, with liver unaffected. Thus, the nature of the diet appears to be an important regulatory factor. Abdul-Razzaq \& Bickerstaffe (1989) observed higher FSR in the proximal small intestine, but not the rumen or abomasum, of sheep offered barley-based rations, processed differently to alter the acetate:propionate yields from fermentation. The situation with food quantity, however, is more confusing. In fasted and fed mature ewes, similar unidirectional leucine fluxes are observed across the portal-drained viscera, suggesting little response (Pell et al. 1986), while for rats both increases (Burrin et al. 1991) and decreases (Merry et al. 1992) in small intestine FSR 
accompanied higher intakes, although in both circumstances total synthesis was elevated with the greater intake. The trends within the present experiment indicate increases in FSR, and probably $A_{s}$, with intake.

The sheep in the current study exhibited significant differences between the rates of protein synthesis in serosal and mucosal fractions, although both showed substantial activity. This agrees with observations in rodents by McNurlan \& Garlick (1981) but not those of Merry et al. (1992), who reported similar rates between the two fractions. Any response to intake in the sheep appeared not to be confined to increased turnover of villi cells but reflected a general response. Indeed, the migration times from crypt to tip for villi cells (approximately $3 \mathrm{~d}$; Attaix \& Meslin, 1991) are considerably greater than the biological half-lives (from $\ln 2 / k_{s}$ ) of mucosal proteins calculated from Table $2(1-1 \cdot 5 \mathrm{~d}$ ). Substantial intracellular turnover of mucosal cell proteins must occur, therefore, and this may be associated with secretory activity but unfortunately data for endogenous protein entry into the GIT of ruminants are scarce and generally unreliable (see Lobley, 1986).

Based on the assumptions that GIT comprises $58 \mathrm{~g} / \mathrm{kg}$ body weight, the proportions by

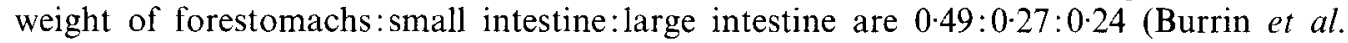
1990), rumen: abomasum is $5: 1$, colon: caecum is $5: 1$ (Attaix, 1988) and the mucosa:serosa is $2: 1$ (G. E. Lobley, unpublished results) then, from Tables 1 and 2, total protein synthesis $(\mathrm{g} / \mathrm{d})$ in stomachs, small intestine and large intestine would be $23,35,12$ at low intake and $40,42,20$ at high intake. The estimated total synthesis values, 70 and $101 \mathrm{~g} / \mathrm{d}$, are approximately $1 \cdot 5-2 \cdot 0$-fold greater than that calculated for the total skeletal musculature of fattening lambs (Lobley et al. 1992), and compatible with GIT:muscle $A_{s}$ of 1.6 determined directly in newly-weaned lambs (Attaix, 1988), where GIT contributed $25 \%$ of whole-body synthesis. No values for absolute synthesis are available for sheep of the size and intake used in the current study but, based on minimum whole-body synthesis rates of $280-320 \mathrm{~g} / \mathrm{d}$ estimated from leucine flux (from Harris et al. 1992), a similar proportional contribution of the GIT to total synthesis appears probable in older growing sheep. Estimated GIT synthesis exceeded that in the liver by three-fold, again comparable to the data obtained in newly-weaned lambs (Attaix et al. 1988).

\section{Translational efficiency}

Values for $k_{r n a}$ for all the splanchnic tissues measured were considerably less than the 18-35 g protein synthesized/d per $g$ total RNA observed by Attaix (1988) for the newlyweaned lamb. While some caution is necessary in making direct comparisons between these two studies, because different methods of measuring RNA were used (u.v. absorbance $v$. orcinol), it would appear that fattening sheep have a reduced capacity to utilize cellular RNA for protein synthesis than do the weanling lambs. Similar ontological declines can be calculated for ovine muscle (see Lobley, 1993) and the reduced FSR which accompanies the lower rates of RNA accretion and translational efficiency may lead to decreased protein gain. Indeed, Searle \& Graham (1987) analysed age-related carcass composition data from several sources and showed that for major commercial species, including various breeds of sheep, there is a sharp positive inflexion in the proportion of fat in the carcass. For sheep this change occurred between 20 and $30 \mathrm{~kg}$ live-weight, but could not be attributed to faster absolute rates of lipid accretion, indeed these remained unaltered during this part of the growth phase, but rather the rate of protein deposition was slowed markedly.

The lower $k_{r n a}$ values for these $>40 \mathrm{~kg}$ animals compared with the newly-weaned lamb (Attaix, 1988) suggest that these may be a contributory factor to the slowed protein gain. The possible mechanisms responsible are legion and include reduced responsiveness to hormones by lowered receptor number, affinity or sensitivity; decreased transcription of key RNA or a decline in factors affecting translation. In the latter case, for example, recent 
studies in rodents have shown a good correlation between the hepatic content of eukaryote initiation factor-2 (eIF-2) and protein synthesis (Kimball et al. 1992) and that the activity of the factor declines with age (Junghahn \& Bommer, 1987; Kimball et al. 1992).

Unfortunately, information on the regulatory changes in ruminants is practically nonexistent and if the inflexion in the rate of protein gain is as sharp as claimed by Searle \& Graham (1987) then a major ontological event must be involved. Identification of that process and the mechanism involved may offer considerable potential for future manipulation of lean tissue growth in commercial species.

This work was sponsored by the Scottish Office Agriculture and Fisheries Department as part of the core budget to the Rowett Research Institute.

\section{REFERENCES}

Abdul-Razzaq, H. A. \& Bickerstaffe, R. (1989). The influence of rumen fatty acids on protein metabolism in growing lambs. British Journal of Nutrition 62, 297-310.

Attaix, D. (1988). Influence de l'age et du sevrage sur la synthese proteique chez l'agneau (Influence of age and weaning on protein synthesis in the lamb). These de Doctorat d'Etat, l'Université Blaise Pascal, Clermont II, France.

Attaix, D., Aurousseau, E., Manghebati, A. \& Arnal, M. (1988). Contribution of liver, skin and skeletal muscle to whole-body protein synthesis in the young lamb. British Journal of Nutrition 60, 77-84.

Attaix, D., Mangehabti, A., Grizard, J. \& Arnal, M. (1986). Assessment of in vivo protein synthesis in lamb tissues with $\left[{ }^{3} \mathrm{H}\right]$ valine flooding doses. Biochimica et Biophysica Acta 882, 389-397.

Attaix, D. \& Meslin, K. C. (1991). Changes in small intestinal mucosa morphology and cell renewal in suckling, prolonged-suckling, and weaned lambs. American Journal of Physiology 261, R811-818.

Bryant, D. T. W. \& Smith, R. W. (1982). The effect of lactation on protein synthesis in ovine skeletal muscle. Journal of Agricultural Science, Cambridge 99, 319-323.

Burrin, D. G., Davis, T. A., Fiorotto, M. L. \& Reeds, P. J. (1991). Stage of development and fasting affect protein synthetic activity in the gastrointestinal tissues of suckling rats. Journal of Nutrition 121, 1099-1108.

Burrin, D. G., Ferrell, C. L., Britton, R. A. \& Bauer, M. (1990). Level of nutrition and visceral organ size and metabolic activity in sheep. British Journal of Nutrition 64, 439-448.

Davis, S. R., Barry, T. N. \& Hughson, G. A. (1981). Protein synthesis in tissues of growing lambs. British Journal of Nutrition 46, 409-419.

Early, R. J., McBride, B. W. \& Ball, R. O. (1988). Phenylalanine metabolism in sheep infused with glucose plus insulin. 1. Effects on plasma phenylalanine concentration, entry rate and utilisation by the hindlimb. Canadian Journal of Animal Science 68, 711-720.

Early, R. J., McBride, B. W. \& Ball, R. O. (1990). Growth and metabolism in somatotropin treated steers: III Protein synthesis and tissue energy expenditures. Journal of Animal Science 68, 4153-4166.

Eisemann, J. H., Hammond, A. C. \& Rumsey, T. S. (1989). Tissue protein synthesis and nucleic acid concentrations in steers treated with somatotropin. British Journal of Nutrition 62, 657-671.

Garlick, P. J., McNurlan, M. A. \& Preedy, V. R. (1980). A rapid and convenient technique for measuring the rate of protein synthesis in tissues by injection of $\left[{ }^{3} \mathrm{H}\right]$ phenylalanine. Biochenical Journal 192, 719-723.

Harris, P. M., Lobley, G. E., Skene, P. A., Buchan, V., Calder, A. G., Anderson, S. E. \& Connell, A. (1992). Effect of food intake on hind-limb and whole-body protein metabolism in young growing sheep: chronic studies based on arterio-venous techniques. British Journal of Nutrition 68, 388-407.

Junghahn, I. \& Bommer, U.-A. (1987). Age-dependent changes in the activity of the cytosolic fraction from rat liver to stimulate polysomal protein synthesis and the role of initiation factor elF-2. Biomedica Biochimica Acta 46, 791-794.

Kimball, S. R., Vary, T. C. \& Jefferson, L. S. (1992). Age-dependent decrease in the amount of eukaryotic initiation factor 2 in various rat tissues. Biochemical Journal 286, 263-268.

Kuhara, T., Ikeda, S., Ohneda, A. \& Sasaki, Y. (1991). Effects of intravenous infusion of 17 amino acids on the secretion of $\mathrm{GH}$, glucagon and insulin in sheep. American Journal of Physiology 260, E21-E26.

Lewis, S. E. M., Kelly, F. J. \& Goldspink, D. F. (1984). Pre- and post-natal growth and protein turnover in smooth muscle, heart and slow- and fast-twitch skeletal muscle of the rat. Biochemical Joumal 217, 517-526.

Lobley, G. E. (1986). The physiological bases of nutrient responses: growth and fattening. Proceedings of the Nutrition Society 45, 203-214

Lobley, G. E. (1993). Species comparison of tissue protein metabolism: effects of age and hormonal action. Journal of Nutrition (In the Press.)

Lobley, G. E., Connell, A., Milne, E., Buchan, V., Calder, A. G., Anderson, S. E. \& Vint, H. (1990). Muscle protein synthesis in response to testosterone administration in wether lambs. British Journal of Nutrition 64. $691-704$ 
Lobley, G. E., Harris, P. M., Skene, P. A., Buchan, V., Milne, E., Calder, A. G., Anderson, S. E., Garlick, P. J. \& Connell, A. (1992). Responses in tissue protein synthesis to sub- and supra-maintenance intake in young growing sheep: comparison of large-dose, and continuous-infusion techniques. British Journal of Nutrition $\mathbf{6 8}$, 373-388.

Lobley, G. E., Milne, V., Lovie, J. M., Reeds, P. J. \& Pennie, K. (1980). Whole body and tissue protein synthesis in cattle. British Journal of Nutrition 43, 491-502.

McNurlan, M. A. \& Garlick, P. J. (1981). Protein synthesis in the liver and small intestine in protein deprivation and diabetes. American Journal of Physiology 241, E238-245.

Merry, B. J., Holehan, A. M., Lewis, S. E. M. \& Goldspink, D. F. (1987). The effects of ageing and chronic dietary restriction on in vivo hepatic protein synthesis in the rat. Mechanisms of Ageing and Development 39 , 189-199.

Merry, B. J., Lewis, S. E. M. \& Goldspink, D. F. (1992). The influence of age and chronic restricted feeding on protein synthesis in the small intestine of the rat. Experimental Gerontology 27, 19-200.

Oddy, V. H., Lindsay, D. B., Barker, P. J. \& Northrop, A. J. (1987). Effect of insulin on hind-limb and wholebody leucine and protein metabolism in fed and fasted lambs. British Journal of Nutrition 58, 437-452.

Pell, J. M. \& Bates, P. C. (1987). Collagen and non-collagen protein turnover in skeletal muscle of growth hormone-treated lambs. Journal of Endocrinology 115, R1-R4.

Pell, J. M., Calderone, E. M. \& Bergman, E. N. (1986). Leucine and $\alpha$-ketoisocaproate metabolism and interconversions in fed and fasted sheep. Metabolism 35, 1005-1016.

Read, W. W., Read, M., Rennie, M. J., Griggs, R. C. \& Halliday, D. (1984). Preparation of $\mathrm{CO}_{2}$ from blood and protein-bound amino acid carboxyl groups for quantitation of ${ }^{13} \mathrm{C}$-isotope enrichments. Biomedical Mass Spectrometry 15, 467-472.

Reynolds, C. K., Tyrell, H. F. \& Reynolds, P. J. (1991). Effects of diet forage-to-concentrate ratio and intake on energy metabolism in growing beef steers: whole body energy and nitrogen balance and visceral heat production. Journal of Nutrition 121, 994-1003.

Schaefer, A. L., Davis, S. R. \& Hughson, G. A. (1986). Estimation of tissue protein synthesis in sheep during sustained elevation of plasma leucine concentration by intravenous infusion. British Journal of Nutrition 56 , 281-288.

Searle, T. W. \& Graham, N. McC. (1987). Patterns in growth. 1. Changes in body fat and protein. Proceedings of the Nutrition Society of Australia 12, 136-140.

Southorn, B. G., Kelly, J. M. \& McBride, B. W. (1992). Phenylalanine flooding dose procedure is effective in measuring intestinal and liver protein synthesis in sheep. Journal of Nutrition 122, 2398-2407.

Webster, A. J. F., Osuji, P. O., White, F. \& Ingram, J. F. (1975). The influence of food intake on portal blood flow and heat production in the digestive tract of sheep. British Journal of Nutrition 34, 125-139. 